IdeAs

Idées d'Amériques

$14 \mid 2019$

Populismes dans les Amériques

\title{
Interview with Tamis Parron and Leonardo \\ Marques, UFF
}

\section{Angélica Müller}

\section{(2) OpenEdition}

1 Journals

\section{Electronic version}

URL: http://journals.openedition.org/ideas/6823

DOI: 10.4000/ideas.6823

ISSN: 1950-5701

\section{Publisher}

Institut des Amériques

\section{Electronic reference}

Angélica Müller, « Interview with Tamis Parron and Leonardo Marques, UFF », IdeAs [Online], 14 | 2019, Online since 01 October 2019, connection on 09 November 2019. URL : http://

journals.openedition.org/ideas/6823; DOI : 10.4000/ideas.6823

This text was automatically generated on 9 November 2019

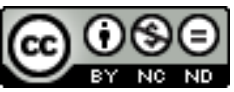

IdeAs - Idées d'Amériques est mis à disposition selon les termes de la licence Creative Commons Attribution - Pas d'Utilisation Commerciale - Pas de Modification 4.0 International. 


\title{
Interview with Tamis Parron and Leonardo Marques, UFF
}

\author{
Angélica Müller
}

In May 2019, the Fluminense Federal University (UFF), located in the city of Niterói, in the state of Rio de Janeiro (Brasil), founded the Center on Global Inequalities, receiving the library, projects, and intellectual heritage of the Fernand Braudel Center, from the Binghamton University. Among the leaders of this project are two young UFF historians, Tâmis Parron and Leonardo Marques. Parron is professor of history of nineteenth century Brazil. He earned his PhD at the University of São Paulo in 2015 and spent a year as postdoc at Harvard University in 2016. In 2012 he earned the greatest Brazilian prize in literature, the Jabuti, for his book A política da escravidão no Império do Brasil, 1826-1865, based on his MA thesis. Leonardo Marques is professor of history of colonial America. He earned his $\mathrm{PhD}$ at Emory University in 2013 and spent one semester as a postdoc at the University of São Paulo in 2015. Among his works is the book The United States and the Transatlantic Slave Trade to the Americas, 1776-1867, published by Yale University Press in 2016.

ANgÉLICA MüLLER: Why was the Fernand Braudel Center created at Binghamton University in 1976 ?

Tamis Parron e Leonardo Marques: The FBC was an innovative institutional and scientific reaction to the global challenges brought by the crisis of capitalism in the 1970s. A number of contradictory processes had been in the making after World War II, such as the end of the reconstruction of Europe, Afro-Asian decolonization movements, and the environmental crisis produced by the so-called "Great Acceleration." After a while, these processes became connected to the oil crisis brought about by the rise of prices by OPEC. The crisis was huge and permanent because oil was, and still is, a key commodity that integrates the main global production chains, regulating the general costs of commodity production and the reproduction of the labor force across the world. The unexpected combination of these events led to rising costs of capital, raw materials, and labor overnight. This challenged the American way of life and created global competitive pressures that redefined the patterns of capital accumulation in the world. The crisis of the 1970s 
led to two contradictory - albeit complementary - global processes: the development of neoliberalism in the Atlantic world and the productive takeoff of the Indo-Pacific, or the displacement of the dynamic axis of industrial production from the Atlantic to the Indo-Pacific.

These transformations - which by the way are at the genesis of the growing inequalities that are shaking democracies today - were the main motivations for the creation of the FBC in the 1970s. At the time, the modernization theory was widely shared as a worldview, formulated by figures such as Walt Rostow, a consultant for US external policies, and sponsored by the US State Department. Rostow used to say that the differences between the economic trajectories of the West (which many reduce to the wealthy countries of the Atlantic) and the rest were produced by the institutional designs of these nations. Poor nations would solve their problems once they started copying the recipes for economic growth from their rich counterparts.

To go back to your question, the general crisis of the 1970s and the collapse of modernization theory created the context for the emergence of the FBC, a research center that sought to explain large scale social change in the longue durée.

Thus when Terence Hopkins and Immanuel Wallerstein founded the FBC in 1976 their first scientific challenge was to understand the world changes of capitalism in the 1970s. They did not want to see them only as the product of their times, but also as the materialization of processes that went all the way back to the early modern period, or, in other words, as the particular expression of a much deeper and long history.

\section{A. M.: Why did they pay a tribute to the French historian?}

T.P, L. M.: The friendship between Wallerstein and Braudel was born when Wallerstein started sending to Braudel the chapters of the manuscript that would eventually be published as The Modern World System (1974), Wallerstein's magnum opus. At the time Braudel was writing Civilization and Capitalism, an interpretation of capitalism in the long run, and read with excitement the ambitious work of a North American scholar that was almost thirty years younger than him. From this came rich intellectual exchanges, with genuine mutual influences. This was one of those dialogues that are both cause and effect of the intellectual greatness on both sides.

Because of this friendship, Wallerstein worked with Braudel for one year at the École des Hautes Études en Sciences Sociales, in Paris, shortly after the publication of the first volume of The Modern World System. When he returned to the United States, his former colleague as a student and professor at Columbia University, Terence Hopkins, invited him to participate in the creation of a center of historical social science on capitalism at Binghamton University. When Wallerstein accepted the offer, the tribute to Braudel seemed to be something natural. After all, Braudel was the intellectual who could best satisfy the demand for a social science capable of explaining the world as a processual totality.

We could go further and argue that Braudel also shaped the ideas of time and space in Wallerstein's work. Wallerstein took very seriously the Braudelian argument that history is the field where all other social sciences could be synthesized because of the dialectic of temporalities: the longue durée, the conjuncture, and the events of the short term. While economists, political scientists, and sociologists deal with shorter 
time periods and anthropologists with the longest, history could reconnect social knowledge with the understanding that social change was a result of the dialectical interaction between the different times of human life. Braudel was indeed very sharp in attributing causal relevance to social times. Before him, scholars such as François Simiand and Ernest Labrousse had already realized that any event in social life comes from the relatively contingent combination of independent causes, which leads to the tracking not of one antecedent but a plurality of combined precedents. Braudel refined this view by interpreting these series of independent causes within stratigraphical levels of time. Wallerstein learned a good deal from this.

Braudel not only offered a complex view of the plurality of social times to Wallerstein, but also allowed him to further explore the idea of historical space. Braudel always emphasized that the space in which human activities develop are not reducible to the homogenous territoriality of national states. Wallerstein managed to incorporate this view and further develop it to its logical conclusion. He argued that the life and rhythms of historical capitalism depended on an essential primary spatial tension: the contradiction between the territorial spatiality of politics (or the State) and the network spatiality of economic activities. Influenced by the Braudelian sensibility to space, Wallerstein allowed us to see that historical capitalism is a system of accumulation that emerges, develops, and experiences multiple crises by manipulating different territorialities: those of social movements, political decisions, and flows of capital.

Finally, it is important to note that Wallerstein also influenced Braudel. The French historian did not seem to be completely aware of how to further develop his argument in Capitalism and Civilization. The third volume was written after a number of exchanges with Wallerstein and especially after Wallerstein stayed at École des hautes études en sciences sociales in the academic year of 1975-76. Braudel himself acknowledged in this third volume (first published in 1979) that Wallerstein's work helped him understand his own interpretation.

A. $\mathbf{M . :}$ How did you get to know the Center?

T.P, L. M.: A very rich dialogue involving a number of Brazilian historians has emerged in the last two decades around the concept of "second slavery", first developed by Dale Tomich (a central figure in the history of the Fernand Braudel Center) by the end of the 1980s. The original idea was relatively simple: the nineteenth century was both the age of abolitionism and of the expansion of slavery in new settings, especially in the western region of Cuba, the Paraíba Valley, in Brazil, and the southern states of the United States. Based on this idea, historians have explored the mutual influences between the different slave societies of the nineteenth century and their place in the capitalist world economy. One of the first collective enterprises that came out of this movement was a comparative study of landscapes and architecture of the second slavery involving Rafael Marquese, Cuban historians Reinaldo Funes and Carlos Venegas, and Tomich himself. In the following years, Marquese and other Brazilian historians such as Ricardo Salles, Mariana Muaze, among others, have engaged in a number of debates, frequently including other members of the second slavery network, which inevitably led to critical discussions around the intellectual tradition that was behind the concept of second slavery. In this context Rafael Marquese and João Paulo founded the Lab-Mundi (2013) at the University of São Paulo with the explicit goal of studying the history of 
Brazil within the framework of the capitalist world system. Since its early days the group had three of the founding members of the UFF Center on Global Inequalities: Douglas Leite, Leonardo Marques, and Tâmis Parron.

In sum, we had been developing a very intense dialogue not only among ourselves, but also with Dale Tomich and other members of the Fernand Braudel Center. In 2017 the three of us happened to be working at the Fluminense Federal University (Douglas is a member of the Law School since 2010, Leonardo became part of the Institute of History in 2015 followed by Tâmis two years later). Since we have a number of intellectual affinities, we soon decided to start some kind of research group at the university. While we started talking to colleagues from different departments, we learned that the Fernand Braudel Center had decided to end its activities. In view of our previous dialogue with the FBC, we started talking to Tomich and Richard Lee (present day director of the Center) to discuss the possibilities of inheriting the resources that the $\mathrm{FBC}$ had accumulated over half a century.

With the help of many people from different departments at UFF, the FBC accepted to transfer its fantastic library of journals and its network to the recently founded UFF Center on Global Inequalities.

A. M.: After more than 40 years at Binghamton University, the FBC resources will be donated to the new UFF Center on Global Inequalities. What is the meaning of this change? What is the meaning of such a change from North to South?

T.P, L. M.: This is a very important point: North-South relations in the contemporary world. We usually tend to think that these relations are based on the flows of goods, people, and capital. In fact, they also include ideas and academic exchanges. Unfortunately, the idea of unequal exchange can be used not only for the world economy but also for global academia.

As you are aware, unequal exchange is the exchange between apparently equivalent things that leads to differential gains and losses for those involved in it. This is precisely what happens in academia on a world level. Usually the international scientific community allows social scientists from the North do develop theoretical knowledge, conceptual frameworks, abstract formulations. When we say "it allows" we want to say "it consumes and publicizes." This same community, however, turns researchers from the Global South into producers of empirical data and local descriptions. Their theoretical production is often ignored. Global academia only cites works that bring raw data, facts, and events.

When you press further to see what exactly is the "North" it soon becomes clear that the North is also unequal: they are basically the Anglo-American universities. It is almost like there is no intelligent life outside the Anglo-Saxon village.

Scholars within the perspective of the world systems were always very skeptical and critical about the unequal exchanges in the material and symbolic levels of the international scientific community. If we leave Braudel aside for a moment, and obvious influences such as Marx, we see that some of the main sources of intellectual inspiration for world system analysis came from the so-called peripheral areas: the idea of center and periphery with the Argentinian Raúl Prebisch; the idea of unequal exchange from Amir Samin and Arghiri Emmanuel; the international dimensions of economic processes from dependency theory; the radicalism of the black Marxism of C.L.R. James, Eric Williams, and Frantz Fanon. World system scholars, among them 
Wallerstein, rejected scientific Anglo-Saxon parochialism. They incorporated the scientific knowledge of the South ("South" here as a geographical metaphor) not as a repertoire of data and facts, but as an intellectual tradition that can also teach something about universal processes. This was evident in the FBC practice of inviting non-US scholars, such as Aníbal Quijano and Walter Rodney. The idea was not to simply replace one tradition for another, which could easily lead to new parochialisms, but to break with the limits established by unequal academic exchanges.

In this sense, the transference and further development of the $\mathrm{FBC}$ tradition at the Federal Fluminense University is completely attuned to the intellectual, political, and ideological agenda of the FBC.

A. $\mathbf{M .}$ : What are the projects for the UFF Center?

T.P, L. M.: The UFF Center was created with the goal of becoming a center of knowledge on the most dramatic problem of the contemporary world: the reproduction of socioeconomic inequality in an increasingly wealthy and connected world.

How can we do this? We have established three non-negotiable values: interdisciplinary and comparative research, participative knowledge, and sensitizing concepts. Let's take a look at each of them.

The scientific production on inequalities has usually been a subject for economists. All the knowledge produced by these scholars is obviously of very high quality. But most economists (a good exception is Thomas Piketty's latest book) tend to emphasize the short and medium terms, focusing on the flows of capital and people. Our focus is on processes that are at the basis of the asymmetrical accumulation of capital by looking at the structured relations of power, geopolitics, world ecology. In other words, the UFF Center will look at the multidimensional and temporal-spatial relations that influence wealth inequality in ways that ideas such as "productivity," "comparative advantages," and "human capital" do not let us see.

How can we do this without reproducing the structures and relations of power that produce inequality within the production of knowledge itself? This is where our second value is important. The UFF Center is a space of participative knowledge. We plan to gather scholars, public policy managers, and social actors from Brazil and other countries to tackle a common problem so that they can create and share ideas and find possible solutions.

Comparative interdisciplinary research and participative knowledge can help us tackle inequality in new ways, and in this the creation of sensitizing concepts, our third value, is important. Sensitizing concepts are those concepts that denaturalize the way we look at the reproduction of social life. Most concepts currently used to understand the contemporary world are shaped by geopolitical interests, by the logic of private enterprises, and the language of capital. The UFF Center wants to stimulate a radical revision of these ideas and replace them with others that can stimulate people to act.

There is something very interesting about this. Brazil is a highly unequal country but it does not have a good social theory on inequality. The paradox of Brazil, if we could frame it this way, is also the paradox of the contemporary world. Our scientific 
utopia is to offer starting points to reorganize our present-day system of diagnostics about Brazil and the contemporary world. A sort of sensitizing that can unleash the convergence of different social forces around common initiatives against the dysfunctional effects of global inequalities.

A. $\mathbf{M . :}$ In his famous article on the longue durée, published in the Annales journal in 1958, Braudel spoke of a crisis in the social sciences, which had been oppressed by their own progress. He then called for a collective work among different sciences (a central part of the Annales) and discussed the centrality of different temporalities for the analysis of historical structures. How relevant are these ideas today?

T. P, L. M.: In the decade following Braudel's classic article, the social sciences went through radical changes brought by various "turns" (linguistic, cultural etc.). Leaving aside a certain melancholy that took over part of the field, historians reacted to these challenges by further diving into the archives, which led to the development of important historiographical traditions.

One of the most important methodological strategies developed by historians was the reduction of scale with micro-history, which, in the French case, emerged as a direct reaction to the work of Braudel. Reducing the scale would let us see the limits of great narratives and understand how structures operated in unexpected ways. Moreover, it would be possible to understand the relations between these different temporalities, connections that Braudel had supposedly neglected. In this sense, part of these works promised to do more than reducing the scale of analysis: the goal was to develop a "play of scales" that eventually led historians back to macro-historical processes. The idea that understanding different times was fundamental for understanding historical structures was somewhat still there.

But developing such a movement was harder to achieve than had been announced. By diving into the archives and reducing the scale of analysis, research questions became increasingly guided by the archive itself, leading to a number of platitudes that appeared as theory, as pointed out by Gary Wilder: the power of the state is never absolute, concrete phenomena are always more complex than their abstract representations, discourses and practices are not always aligned, humans are capable of acting even under the most oppressive conditions, so on and so forth. It is not a coincidence that the concept of capitalism nearly disappeared, occasionally appearing only in the introductions and conclusions of history books.

The other aspect of Braudel's classic article that you raise - the need for a collective work involving different sciences - was also relatively abandoned in this context. While going to the archives strengthened history as a discipline and allowed it to survive for the last half century, with some theoretical and methodological appropriations from Anthropology, the possibility of a deeper dialogue between different disciplines became very restricted. To cite only one example of the limits established by this movement, take a look at the recent comment by Giovanni Levi that reinforces the divide between disciplines. He says that micro-history and connected histories have been connected to Anthropology while the so-called global history has been more akin to the "reductionist syntheses" of sociology.

However, a different tradition came out of the original dialogue between the second generation of the Annales school and world systems scholars. While micro-history was becoming increasingly popular among historians in the 1970s and 80s, a group of scholars developed a critical dialogue with (and within) the Fernand Braudel Center. 
When we take a careful look at the works of Sidney Mintz, Michel-Rolph Trouillot, Eric Wolf, Philip McMichael, and Dale Tomich, among others, we see that some of the same issues are also there: the dynamic relationship between the parts and the whole, between the micro and the macro, between the different temporalities of history. The responses that came out of that context imploded with disciplinary divisions, showing the richness of approaches that crossed the frontiers of History, Anthropology, Sociology, Geography, Economics, among other disciplines.

What is the relevance of Braudel's original premises? At a time when scholars debate the possibility of using a new geological category - the anthropocene - to describe the impact of human actions on the environment and the possibility of human extinction itself in the near future, the collective work involving different sciences should not be seen as a desirable possibility but as an inevitable necessity. Human actions are a product of different forms of economic, political, and sociocultural organization that change over time. Understanding these transformations and, especially, the role of capitalism as a historical system (with all its asymmetries on multiple levels) in these developments is one of the most urgent tasks of contemporary science.

In this sense, besides the necessity to transcend traditional disciplinary divisions, the Braudelian idea of a plurality of times is still very useful. His interpretation was certainly a product of its time, as Dipesh Charkrabarty argues. Still, by avoiding to look at nature as context, Braudel showed possible ways of incorporating the environment into the analysis. One of the problems in his original formulation was that the determinations from nature were usually cyclical, the cycles of nature affecting humanity. Our own time in turn has produced a vast unpredictability regarding the environment (something that was still not evident when he first published The Mediterranean), with devastating consequences for the present and future of humanity. The environmental crisis is obviously connected to the economic, political, and sociocultural crises that we are experiencing on a global level today. Braudel, Wallerstein, and the alternative tradition described above offer very effective tools to understand our present and possible futures.

A. M.: What are the challenges of producing a history of inequalities on a global scale?

T. P, L. M.: They are many. One of the main ones is to build interdisciplinary debates that can show the historical dimensions of contemporary inequalities and transcend the limits of a methodological nationalism that is still very influential in the social sciences until today.

As we said earlier, most debates on inequality are conducted by economists and focus on the short and medium term. Economic historians have in turn explored the theme in the long run but usually influenced by a very strong methodological nationalism. They usually look for an essential factor that explains economic growth (such as well defined property rights, broader political participation, higher levels of education etc.) and then build a recipe to be followed by developing countries. The focus is on internal dynamics, which appears both in their historical interpretations and in the recipes to end contemporary inequalities, as if these changes depended on measures that could be exclusively taken in the national political sphere.

Systemic processes - and the idea of capitalism itself - are usually neglected or naturalized. Deeper aspects of the system are rarely the object of discussion. In a sense, some of the debates of the mid-twentieth century are still with us, in renewed 
versions of the old modernization theory. However, if reifying the idea of economic growth and development was already problematic in the old days of the Cold War, as Wallerstein and others pointed out at the time, today this is leading us to collapse. The environmental crisis and its brutal consequences for human life should inevitably force us to think of strategies that transcend the limits of national states. To go back to something we have already said, it is necessary to think the structures that led us to where we are. Collective work that can transcend the frontiers between different disciplines and academia itself are fundamental for this. Fortunately, this kind of work is already emerging. Our hope is that the UFF Center can contribute to their further development.

\section{AUTHOR}

\section{ANGÉLICA MÜLLER}

Professor of history of Brazil Republic of the Fluminense Federal University (Rio de Janeiro Brazil) and associate researcher of the CHS/Paris 1. Productivity fellow of CNPq and Young Scientist of state Faperj. She is currently the editor of Tempo review and a member of the international editorial committee of IdeAs review. 